\title{
IS QIȘĀSS (JUST RETRIBUTION) FOR INTENTIONAL BODILY HARM ENTIRELY BASED ON IJMA'?
}

By:

Muhammad Amanullah

\begin{abstract}
Some contemporary scholars maintain that the rules relating to qișas (just retribution) for bodily harm are based entirely upon ijma $\bar{a}^{\prime}$. Homever, works by the Hanafi jurists seem to suggest that other sources of law are important as well. This article attempts to elaborate the issue by focusing on the discussion by those jurists of the conditions of implementing just retaliation for bodily injuries: equality of injuries, possibility of implementing just retribution, equality of the parties with respect to both being free persons, equality of the parties with respect to gender, and the determination that the injury suffered by the victim is permanent.
\end{abstract}

\section{INTRODUCTION}

The Islamic penal code embraces three major types of sanctions: fixed penalties ( $h u d \bar{u} d)$, discretionary punishment $\left(t a^{\prime} z \bar{i} r\right)$ and private just retribution (qișass). Among these, private just retribution constitutes a sanction against homicide and bodily harm, both of which fall under the heading of jinäyāt. In contrast to the other types of sanctions, implementation of this type depends entirely upon the decision of the victim or his or her nearest of kin. 
Jurnal Fiqh: No. 2 (2005)

The rules relating to just retribution for homicide have been dealt with by a number of modern scholars, but those relating to just retribution for bodily harm have not received the same degree of attention. In this study I would like to explore the theoretical foundations of the latter category of rules as these are laid out in certain Hanafi works of figh. In so doing I hope to make a small contribution to the understanding of how the principles of ușul al-figh impact figh.

Some contemporary scholars who, to my knowledge, have briefly addressed this subject, mainly Hideaki Homma, Mahmūd Shaltūt and Mohamed El-Awa, have maintained that the rules relating to just retribution for bodily harm are based entirely upon ijm $\bar{a}^{\prime}{ }^{1}$ My reading of Hanafi works has led me to a different conclusion. Although $i j m \bar{a}^{\prime}$ plays a role, Hanafi thinking gives importance to other sources of law as well. I will try to handle this issue through discussing the conditions of implementing just retaliation for bodily injuries.

\section{CONDITIONS OF IMPLEMENTING JUST RETALIATION FOR BODILY INJURIES}

The rules in question lay down five conditions governing the implementation of just retribution for bodily injuries: equality of injuries, possibility of implementing just

Hideki Homma (1986), Structural Characteristics of Islamic Penal Law Niigtken: The Institute of Middle Eastern Studies, International University Japan, p. 70; Mohmed S. El-Awa (1993), Punishment in Islamic Law Indianapolis: American Trust Publications, pp. 72-73.

2 'Alā' al-Dìn Abū Bakr ibn Mas'ūd al-Kāsāni (1972), Badā'i' al-Sānā'it' fí Tartīb al-Sharā' $i^{\prime}$, Cairo: Maṭba'at al-Īmān, 10: 4761-4762, 4791-4792. Al-Kāsāni does not include "waiting" as part of the conditions. Rather, he mentions it separately. Since it is an obligation according to Hanafi scholars, I have listed it mong the conditions. 
Is Qișăș (Just Retribution) for Intentionally Bodily Harm Based on $\operatorname{ljm} \bar{a}{ }^{‘}$ ?

retribution, equality of the parties with respect to their both being free persons, equality of the parties with respect to gender, and the determination that the injury suffered by the victim is permanent. ${ }^{2}$

Let us begin with the condition of equality of injuries. This condition requires that the injured body part of the victim and the body part of the offender upon which retaliatory injury is to be inflicted must be equal in functional importance. This means, for example, that a right hand cannot be injured as retaliation for the injury of a left hand. Among the Qur'annic verses cited in discussions of this condition, three are specially prominent. Two are quite similar:

Allah said: "The one who transgresses against you, transgress against him in a way that is similar to his transgression against you. ${ }^{\prime 3} \mathrm{He}$ also said: "If you want to punish [someone], punish him in a way that is similar to what you have been punished with." ${ }^{\prime 4}$

Both of these verses employ the word mithl, thus underguarding the principle of mumathalah, or equality, but the language they employ is general, and they do not define the equality in question in precise terms.

Much more central to the discussion is the third verse: "I made obligatory upon them [the Jews] in it [the Torah] a life for a life, an eye for an eye, a nose for a nose, an ear for an ear, a tooth for a tooth, and injuries are subject to just retribution." 5 This verse makes it clear that just retribution for bodily harm entails a matching of body

\footnotetext{
Al-Baqarah, 2: 149.

Al-Nahl, 16: 126.

5 Al-Mā'idah, 5: 45.
} 
Jurnal Fiqh: No. 2 (2005)

parts, but the principle of equality of functional importance is still not explicitly affirmed. ${ }^{6}$

It is interesting to note in passing that some Muslim exegetes, as al-Kāsāni remarks, tried to invalidate the use of this verse on the ground that it pertained to what was in an earlier revealed law, namely the Torah, and therefore did not apply to Muslims. Al-Kāsāni argues that this provision of the Torah has never been abrogated by either the Qur'ān or the Sunnah and that what has not been abrogated still applies. Likewise, he argues that some known reciters of the Qur'an do not connect the words wa al-'ayn bil-'ayn "and an eye for an eye" with the preceding words anna al-nafsa bil-nafs "a life for a life," that are recited with nasb (accusative). Rather, these reciters start a new sentence from wa al-'aynu with raf' (nominative) that continues up to the end of the rules mentioned in this verse. Therefore, the rules discussed in the subsequent parts of this verse are not connected with its first part, which refers to the Torah. Hence these rules are not considered to be mere information about the rules of the previous Shari'ah. Rather, they are rules of the Islamic Shari'ah. ${ }^{7}$

How, then, do the Hanafi jurists establish the principle of equality of functional importance? Here consensus enters the picture. Al-Jașṣāṣ and al-Sarakhsi both cite the following statement as expressive of a consensus of scholars: "A sound hand should not be amputated [in retaliation] for a paralyzed one, because they are not equal." This consensus clearly places a restrictive interpretation on the Qur'änic dictum, "a hand for a

6 See Abū Bakr Aḥmad ibn 'Alì al-Jașșās (1970), Ahkâm al-Qur'ān, Beirut: Dār al-Kitāb al-'Arabī, 1: 160.

7 Al-Kāsāní, 10: 4761-4762. 
Is Qisă $\bar{s}$ (Just Retribution) for Intentionally Bodily Harm Based on Ijmã ‘?

hand." We are able to conclude that just retribution does not mean just any hand for any hand.

But this consensus mentions only a particular case: a sound versus a paralyzed hand. In order to establish the principle of equality of functional importance as a general principle applicable to a variety of cases, the jurists must go beyond this consensus. They are able to do this by using this consensus as a basis for an analogy. If a sound hand cannot be taken in retaliation for a paralyzed hand, then, by analogy, a dominant and more vital right hand cannot be taken in retaliation for less vital left hand, and so on.

Al-Kāsāni provides another analogical deduction by saying that the limbs bear the status of property because just like property, they are created to protect life. Since maintenance of equality of property for the payment of destroyed wealth is obligatory, maintenance of equality between two limbs in observing just retaliation also should be obligatory. ${ }^{9}$

But Hanafi figh is able to call upon another important source of law to reinforce the principle of equality of functional importance, namely the $\bar{a} t h \bar{a} r$, or statements of major figures among the early generations of Muslims. In his Kitāb al-Aṣl, Muḥammad al-Shaybānì attributes the following doctrine to Ibrāhim al-Nakha'i: "The right hand is not to be taken for the left, nor the right foot for the left, nor the hand for the foot, nor the thumb for any other finger, nor a finger for a toe, nor a bone for a bone except the teeth",,$: 10$ A thăr are not, of course, counted among the

8 Al-Jașșāș, 1:138-140; Shams al-Dīn al-Sarakhsi, Kitāb al-Mabsūț, Cairo: Maṭba'at al-Sa'ādah, (A.H. 1324-1331, i.e., A.D. 1906-1913), 26: 136.

Al-Kāsāni, 10: 4761-4762.

$10 \mathrm{Abū}$ 'Abd Allāh Muhammad bin al-Hasan al-Shaybāni (1990), Kitāo al-Aṣl al-Ma'rūf al-Mabsūṭ, ed. Abū al-Wafā' al-Afghānī, Beirut: 'Ālam al-Kutub, 4: 439-446. 
four agreed sources of the law, but they can have weight in shaping juristic opinion. Again, the principle of equality of functional importance is not expressly stated, but it is strongly implied.

The second condition governing just retribution for bodily harm is that it must be possible to implement the retaliation in a manner that does not violate the principle of equality. Al-Jașșās seems to regard this condition as implicit in the third of the Qur'ānic verses cited above. Al-Jașsāṣ contrasts "an ear for an ear" with "a nose for a nose." The ear can be removed in its entirety as retaliation for destruction of an entire ear, but this is not true of the nose, because the base of the nose is made up of bone and bone cannot be injured with precision. Thus upon reflection upon these Qur'anic provisions we come to realize that just retribution involving the entire nose, including its base, is not possible and so should not be undertaken. ${ }^{11}$

Al-Sarakhsi, on the other hand, turns to $\bar{a}$ thār, quoting a saying of 'Umar "There is no just retribution for bones," and a saying of Ibn 'Abbās, "There is no just retribution for those bones for which a fear of destruction exists." 12 These $\bar{a}$ thär thus establish an important category of injuries that cannot be subject to just retribution, namely injuries to bones or at least certain bones, because similarity cannot be maintained.

The third condition governing just retribution for bodily harm is that both the offender and the victim be free persons. If one is free and the other is a slave, or if both are slaves, just retribution cannot be undertaken. Here the arguments used by the Hanafi jurists all involve analogical

11 Al-Jașșāṣ, 2: 440-441.

12 Al-Sarakhsi, 26: 146. 
Is Qișās (Just Retribution) for Intentionally Bodily Harm Based on ljmā'?

deductions from the principle of equality of injuries discussed earlier. For example, al-Jașsāạ and al-Kāsāni argue that since a sound hand is not equal to a paralyzed one - a point supported by a consensus of jurists, as we have seen - and since a hand with all fingers intact is not equal to a hand with fewer than five fingers, a limb of a free person is not equal to the limb of a slave. The limb of a free person, being unrestricted by the limitations that apply to slaves, is of greater functional importance than the limb of a slave. Hence just retaliation for limbs cannot be implemented between a slave and a free person.

Likewise, just retaliation for limbs among the slaves should not be implemented because their prices are different. Therefore, equality cannot be maintained. ${ }^{13}$

Arguments for the fourth condition - equality of gender - are similar. Here again the dictum upheld by consensus, "A sound hand should not be amputated [in retaliation] for a paralyzed hand because they are not equal," becomes the basis for an analogy. Both al-Jașsās and al-Sarakhsi argue, accordingly, that just as a sound hand is not equal to a paralyzed hand, man's limb is not equal to a woman's limb. However, just retaliation for injuries among women should be implemented because their limbs are equal. ${ }^{14}$

Al-Kāsāni provides a different analogical deduction for the inequality of male and female limbs. He argues that the compensation for a female limb is half of the compensation for a male limb. Just retaliation for injuries among men and

13 Al-Jașşạs, 1: 135-136; Al-Kāsāní, 10: 4791-4792. A coincidental equality between the price of the limbs of a slave and that of another slave is not counted because their prices are estimated by the estimators, who do not care about equality. However, blood money should be paid for these limbs.

14 Al-Jașsāạ, 1: 138-140; Al-Sarakhsĩ, 26: 136. 
Jurnal Fiqh: No. 2 (2005)

women, therefore, is not valid. ${ }^{15}$ By either argument the all important condition of mumāthalah is not met.

Certain non-Hanafī jurists such as Ibn Abi Layla', Mālik, al-Thawri, al-Awza' ${ }^{\prime} \bar{i}$ and al-Shāfi'i are said to have regarded injuries to male and female limbs are equal, preferring to take as the starting point of their analogical argumentation the principle of "a life for a life." Since the life of a man is deemed equal to a life of a woman and since the limbs are components of a full life, the limbs should be granted the same equality. ${ }^{16}$ Although this view is not accepted by Hanafis, it is worth mentioning that the members of this opposing camp justify their views through an analogical deduction based on a rule mentioned in the Qur'ān, not on an $i j m \bar{a}^{\prime}$, i.e., the rule of "a life for a life."17

The fifth condition states that judgment regarding just retribution for bodily harm must be postponed until it is determined whether healing will occur and permanent injury will not result. The Sunnah comes into the picture in Hanafi argumentation in regard to this condition alone. One of the ahaddith in question was related by Abu Hanifah himself on the authority of Jābir. It reads: "The Messenger of God said: 'An injury is not subject to just retribution until it is [determined if the injury is] cured. ${ }^{\prime \prime 18}$ Another Hanafi $\bar{i}$ scholar, al-Ṭahāwi $\bar{i}$, related a slightly different version of the same Hadith according to which the parties

\footnotetext{
15 Al-Kāsānì, 10: 4792.

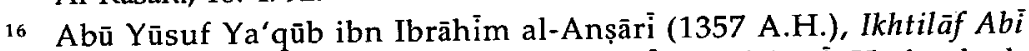
Haniffah wa ibn Ab $\vec{i}$ Layla', ed. Abū al-Wafí' al-Afghäni, Hyderabad: Lajnat Ihỵā al-Ma'ārif al-Nu'māniyyah, pp. 147-148; Al-Sarakhsí, 26: 136.

17 This rule is based on Surat al-Mā'idah, 5: 45.

18 Abū Hanifah (1981), Musnad al-Imām Abi Hanifah, Cairo: Maktabat alAdab wa Maṭba'atuhā, p. 170.
} 
should allow a full year to pass. ${ }^{19}$ Al-Kāsāni cites another Hadith, which reads: "When a man injured Hassān ibn Thäbit's thigh bone, the Anșār came to the Messenger of God and claimed just retaliation. The Prophet said: 'Wait for what is going to happen to your companion. By God, I too am going to wait for that." 20

To these arguments from ahadith al-Ṭahāwi and al-Kāsāni add some supplementary reasoning. The implementation of just retribution, they say, relates to the permanent effect of the injury, not to the immediate injury as such. The effect can be determined only after a period of waiting. Therefore, such a period is required. ${ }^{21}$ For example, if a man's tooth is loosened as a result of a blow, it is necessary to wait a year during which time the tooth will either stabilize or fall out or become discolored, all of which are different outcomes calling for different rulings. ${ }^{22}$

\section{CONCLUSION}

To conclude, only one expression of the scholarly consensus or $i j m \bar{a}^{\prime}$ is cited throughout all the argumentation of the Hanafī jurists relating to just retribution for bodily harm, and that takes the form of the dictum, "A sound hand should not be amputated for a paralyzed one because they are not equal." This expression of the consensus plays an important role but it is used in conjunction with a complex line of arguments that employ Qur'ānic verses,

Abū Ja'far Aḥmad ibn Muhammad ibn Salāmah ibn 'Abd al-Mālik ibn Salmah al-Azdi al-Ṭahāwỉ (1968), Sharh $M a^{\prime} \bar{a} n \bar{i}$ al-Āthār, ed. Muhạmmad Zuhrỉ al-Najjār, Cairo: Maṭba'at al-Anwār alMuhammadiyyah, 3: 184.

20 Al-Kāsānì, 10: 4792-4793.

21 Al-Ṭaḥāwỉ, 3: 184; Al-Kāsāní; 10: 4792-4793.

22 Al-Sarakhsi, mentioning some similar ahädith, discussed this example. See al-Sarakhsi, 26: 97. 
Jurnal Fiqh: No. 2 (2005)

analogical reasoning and citation of $\bar{a} t h \bar{a} r$. Prophetic ahädith come into the picture only with reference to the waiting requirement. It is certainly not the case that Hanafi thinking about just retribution for bodily harm rests entirely, or even primarily, on $i j m \bar{a}^{\prime}$. 